\title{
Analysis of Sustainable E-Logistics Activities with Analytic Hierarchy Process
}

\section{Cansu ÇAKILCI iD a Yücel ÖZTÜRKOĞLU iD b}

a Graduate Student ,Izmir, Turkey, Graduate Student. cakilcicansu@gmail.com

b Department of International Logistics Management, Yasar University, Izmir, Turkey. yucel.ozturkoglu@yasar.edu.tr

\begin{tabular}{|c|c|}
\hline ARTICLE INFO & ABSTRACT \\
\hline $\begin{array}{l}\text { Keywords: } \\
\text { Environment } \\
\text { E-logistics } \\
\text { AHP }\end{array}$ & $\begin{array}{l}\text { Purpose - The aim of this study is to determine the success factors that are critical for sustaining e- } \\
\text { logistics activities with increasing internet shopping. In order to achieve this aim, economic, } \\
\text { environmental and social dimensions, which are the three important dimensions of sustainability, } \\
\text { have been discussed. }\end{array}$ \\
\hline $\begin{array}{l}\text { Received } 10 \text { November } 2019 \\
\text { Revised } 27 \text { February } 2020 \\
\text { Accepted } 5 \text { March } 2020\end{array}$ & $\begin{array}{l}\text { Design/methodology/approach - Firstly, a detailed literature review conducted to determine the all } \\
\text { impacts of e-logistics activities. Three main and six sub-criteria (transportation, traffic, physical } \\
\text { location, energy, land use, cost, packaging, emission and e-waste) were divided into classes } \\
\text { according to the triple bottom line perspective. These criteria, are investigated by using Analytic } \\
\text { Hierarchy Process (AHP), one of the decision-making techniques, to rank and assign weight of each } \\
\text { sub-criteria. }\end{array}$ \\
\hline \multirow[t]{2}{*}{$\begin{array}{l}\text { Article Classification: } \\
\text { Research Article }\end{array}$} & $\begin{array}{l}\text { Findings - The AHP results showed that carbon emission has the most influence on the } \\
\text { sustainability and then physical location is the second most important e-logistics factor. Land use } \\
\text { has the lower weight that means, there is a little effect of e-logistics activities and e-waste is almost } \\
\text { at the end of the list. }\end{array}$ \\
\hline & $\begin{array}{l}\text { Discussion - As a result, this study contributes to both the academia and industry with its novelty } \\
\text { to integrate sustainability dimensions with e-logistics operations. Based on the results, the increase } \\
\text { in internet shopping significantly increases carbon emissions in terms of environment perspective. } \\
\text { In social dimension, it affects the use of physical locations. Consumers are now shopping online } \\
\text { rather than shopping at physical stores. Therefore, the stores are closing and socially different } \\
\text { consequences arise. When the results are taken from the economic point of view, logistics costs are } \\
\text { highly affected. Companies need to close stores and open a warehouse or distribution center. }\end{array}$ \\
\hline
\end{tabular}

\section{Introduction}

Information and communication technology (ICT) has been improving day by day with the globalization. In particular, internet usage has significantly influenced the way people socialize, learn, work and it has also changed the way cope with daily tasks such as, shopping. Electronic commerce (E-commerce) is the online platform where in buying and selling of products and services both regionally and globally. According to OECD, which has defined the E-commerce in 2001, "E-commerce is an electronic transaction is the sale or purchase of goods or services, whether between businesses, households, individuals, governments, and other public or private organizations, conducted over computer-mediated networks". E-commerce is also defined as the utilization of electronic means and technologies to conduct commerce (Manzoor, 2010:49). Electronic logistics (E-logistics) is commonly defined as processes necessary to transfer the goods sold over the Internet to the customers is one of the most important part of the e-commerce (e-trade). Besides, E-logistics is the application of Internet based technologies to traditional logistics processes (Auramo et al., 2002:513).

E-commerce has some advantages to end users in terms of availability of the products at lower cost with wider product variety on the internet and time saving as well as expend minimum effort. In addition, e-logistics has some opportunities as well as threats to the environment that including, greenhouse gas emissions, energy consumption, fuel consumption, air pollution and plastic and paper waste (Caliskan et al., 2017:148). The carbon emissions associated with daily transportation and business actions is the top concern for the environment (Ozturkoglu et al., 2016:209). Today, some firms have work-flex friendly policies with the effect of changing work structure, which means they allow its employees to working from their home. Telecommuting is a viable way in order to reduce air pollution, needed physical space, energy consumption, and congestion in traffic as well as 


\section{C. Çakılcı - Y. Öztürkoğlu 12/1 (2020) 489-497}

transportation-related carbon emissions. Also, teleconferencing is one of the major solution to reduce carbon footprint and paper consumption. People in different locations can meet with each other in a digital platform and do business by using teleconferencing systems. E-commerce has provided lower environmental impacts than business travel (Toffel and Horvath, 2004:2963; Öztürkoğlu and Demir, 2019: 1907). Reducing the numbers of vehicle travel on the road in a day entail to reduce greenhouse gas emission on the atmosphere, which directly contributes to global warming (Sabegh et al. 2016:983). Usage of bio-fuel is rather than fossil fuel may be second alternative but this will cause an increase in the selling price of the products. Digitization of information system is one of the positive environmental impacts of the e-commerce (Sui and Rejeski, 2002:156). The rate of redundant paper consumption is destroyed with send out bills or contract via the Internet rather than using traditional tools. Reduction in materials consumption would provide a big advantage for deforestation.

More warehouses would be need with fewer physical malls to procure raw materials from suppliers to manufacturing companies and delivering all these products over the Internet to the customers. Sales returns are one of the important factor affecting increase transport emission (Dalgakıran and Öztürkoğlu, 2017:149). For instance, deliverer may not reach customers to deliver their packing in the most of the time because of working hours, that means to needed additional journeys, increased transportation costs, and spending more time. Therefore, all warehouses should be near located at major road for the sooner response to customer orders and reducing energy consumption (Dumlupınar and Öztürkoğlu, 2019: 4).

E-commerce encourages 'mass customization' considering 'just on time or just for you' manufacturing which contributes to eliminate waste; warehouse space, need for inventory, overproduction and the usage of electricity of building and machines. However, e-commerce tends to rise the individual orders than wholesale selling. Thus, vehicles tend to transport of inventories and merchandises on half empty. In terms of energy consumption, faster transportation mode is the vital criteria for e-commerce but which can increase fuel consumption exponentially because companies have to choose airline and truck instead of railway and boats (Daniel and Grimshaw, 2002:140). Indeed, e-commerce comes to use more packaging and labelling of products because of the large amount of individual orders with smaller size than the traditional retailing. Increased the percentage of e-waste gives significant harmful on human health and environment. For example, the production of those semi products cause large amount of air emission, water emission and waste like a silicon and solvents. In additional, just a standard PC has consumed 150W per hour. These electronics have the huge amount of energy consumption.

There are very limited studies that analyses the environmental impact of e-commerce with different perspectives. Fichter (2008) has discussed three environmental impacts of e-commerce and the internet as first, second and third-order effects and presented business approaches for developing of sustainable ecommerce solutions. Pålsson et al. (2017) explained the main energy-consumption factors including sale returns, packaging, buildings, passenger and freight transport and compared their environmental impacts with aid of the 11 studies and 16 cases for both e-commerce with home delivery and traditional stores. Bertram and Chi (2018) analysed and compared the environmental effects between online retailing and traditional retailing regarding carbon emission, waste consumption and energy usage in transportation, packaging, sales return and disposal stages of apparel industry via the current studies on e-commerce's influence on consumer shopping behaviors. Oláh et al. (2018) highlighted that how to integrate environmental, social and economic dimensions to more sustainable e-commerce for next generations. A case study involving two companies that one company is e-commerce retailer in Kenya and Jordan are selected in order to data collection. The three main findings of the study showed that communication with integration among all the partners is one of the key source that sustainable e-logistics is achieved. Second one is trade-off should be in various dimensions to have more sustainable e-logistics process.

However, there is a lack in knowledge in terms of integrating sustainability and TBL with e-logistics activities. Therefore, up to our knowledge, this is the first study to fill that gap in the literature. Therefore, in this study, e-logistics activities are examined under the triple bottom line perspective of the sustainability with all three dimensions. The criteria affecting e-logistics will be found through a detailed literature review since there are not many studies in this respect. Weights of each criterion will be calculated in order to reflect the real industry practices. These calculations will be calculated by Analytic Hierarchy Process (AHP) method based on expert 


\section{C. Çakılcı - Y. Öztürkoğlu 12/1 (2020) 489-497}

opinions. Therefore, the main objective of this study is to identify the impacts of e-logistics with the sustainability regarding positively and negatively directions.

\section{Literature Review}

Many scholars studied the e-commerce and explored various positive and negative effects. But there are a few studies to investigate the environmental effect of e-logistics activities.

Cairns (1999) explained e-commerce has turned many homes into offices and online shopping platform. Companies may allow their employees to work in virtual office. Reducing the numbers of commuters on road with growing of e-commerce tends to reduce their carbon foot print and conserve energy. Caudill et al. (2001) stated that e-commerce encourages privatization with just-in-time production understanding. Manufacturer produces the products that are needed by end user. This causes some potential reductions; need for inventory and warehouse space as well as product waste. Mass customization has environmental benefit to less energy consumption of machines and warehouses. Matthews et al. (2002) examined the relationship e-commerce and environmental sustainability on theoretical level. Arnfalk (1999) evaluated to how teleworking and teleconferencing have used by businesses to eliminate on environmental impacts. Williams and Tagami (2001) analysed the energy use for one book retailing in Japan associated with four different factors. Fossil fuel used by shipper and courier service, by the consumer on the road from home to the book store, energy used for producing packages and energy consumption for lighting, heating and air-conditioning and compared all these factors among e-retailing and in-store retailing. The findings showed that urban population density and the amount of books per order are very important criteria for environmental performance. Traditional retailing system has consumed less energy in dense urban area than e-commerce because e-commerce needs additional packaging and fuel used by courier. When the population density decreases, e-commerce system begins to save energy. Siikavirta et al. (2002) studied on environmental effects in terms of transport emission for only food sector within B2C retailing from grocery store to customer's home. They developed a Geographic Information System (GIS) using the TransCAD program to calculate the shortest distance traveled in London. Due to this system, they calculated that a $70-80 \%$ reduction in distance was possible when preparing a delivery route for the food industry. Romm et al. (1999) explained the energy consumption with the impacts of the growing of Internet economy in United States related to comparing two different periods. First time period is from 1992 to 1996 and second one is after 1996. They finalized the positive impacts of e-commerce on environment in business-to-customer (B2C) retailing. Prouty (2000) highlighted e-commerce shows manufacturing companies the fluctuations of demand truer in the future by taking customer orders on online platform. As a result of that, companies may decrease overproduction rate. This pull-controlled manufacturing situation creates energy saving of warehouses and machines and slightly can be decreased environmental pollutions considering water and air pollutions. Orremo and Wallin (2000) looked the percentage of transport emission while comparing between home deliveries and shopping with those of car by people.

Hurst (2001) has focused on the consumption of paper as another basic assessment. It is not required to send out bills via using papers as traditional means by moving businesses and processes on online. Moving from printed catalogues to web sites entails reduction of material consumption. 'Paperless office' would be advantageous for deforestation which contributes to global warming. Reijnders and Hoogeveen (2001) pointed the energy implication of e-commerce. They have taken PC distribution as a case study; Dutch online computer reseller and they have discussed to where and when to need energy usage such as distribution of these electronic products, energy consumption for PC's usage and warehousing space requirement. As a one of the result of this study, usage of energy is getting to increase with increased online customer's buying power. Matthews and Hendrickson (2001) compared the environmental performances between traditional retailing and e-commerce logistics network and conducted a case study with life cycle assessment (LCA) tool for book retailing sector in United States and Japan. Matthewset and Hendrickson (2001) focused on energy consumption and the amount of gas emission considering shipping distance from publisher to customer home, energy consumption by computer, impact of return rate, packaging, fuel production and other important parameters.

Tuerk (2001) and Abukhader and Jonson (2003) have discussed three potential impacts of e-commerce and internet as primary, secondary and tertiary effects. First effect shows that e-commerce prevent release of large amount of gas emission around the world because there is no need to have physical location to online advisory 


\section{C. Çakılcı - Y. Öztürkoğlu 12/1 (2020) 489-497}

service and online billing system. This tends to decrease building energy use. Secondary effect indicates huge amount of customer orders with smaller size than experienced in the conventional purchasing system so more packages have consumed than traditional retailing. Durable and reusable packages happened as a new perspective of packaging issue in this matter. Tertiary effect of e-commerce is about large amount of saved paper consumption. Sui and Rejeski (2002) identified transportation is a closer cause on environmental impact of the e-commerce. It is responsible for a large percentage of carbon dioxide emission. Reducing the numbers of vehicle trip is one of way for reducing the level of carbon emission. They emphasised the e-commerce tends to need faster transportation modes instead of rail transport which may increase fuel consumption exponentially. Just in time delivery methods tends to create a situation, which in trucks are moved half empty. Sui and Rejeski (2002) analysed the positive environmental impacts of the emerging digital economy considering three Ds; dematerialization, decarbonisation and the last one is demobilisation. Hesse (2002) analysed the impacts of e-commerce on transportation of inventories, logistics and physical distribution especially business-to-business and business-to-customer e-retailing. Yi and Thomas (2007) explained the potential positive and negative environmental impacts of the emerging digital economy. Macauley et al. (2003) attempted to model the costs and benefits of policies to manage e-waste and found the negative health effect of e-commerce because computer and other parts particularly computer monitor easily obsolete due to technological innovation and this generates the problem of e-waste and it creates significant environmental pollution. Environmental concerns in this subject were associated with waste of the lead embodied in cathode ray tubes that are used in most computer. Berkhout and Hertin (2004) developed just a model of the monetary theory on environmental impacts of teleworking. They have selected the model of urban analyses in City of Spanish with a case study using four different dimensions; annual savings in air pollutions, annual saving in traffic congestion, environmental costs of urban relocation and the net environmental savings of e-commerce. Padayachee (2008) investigated the relationship between the use of e-commerce and $\mathrm{m}$-commerce technologies in terms of reduction of carbon emissions in South Africa. The result showed that these technologies have provided a unique advantage to businesses in terms of reducing operating cost and carbon emissions.

Edwards et al. (2010) examined the impacts of e-commerce on environment for unsuccessful home delivery when some people may not at home to receive their orders during working day. Failed deliveries generate the additional carbon dioxide emission. They presented the carbon intensity of last mile deliveries from home delivery to conventional shopping travel in non-food retail store. Tiwari and Singh (2011) explored the positive and negative effects of e-commerce on environmental and researched spreading awareness of both of these impacts on people in the society and studied the impact of e-commerce on environmental sustainability in the enterprises. Khurana et al. (2011) analysed the impacts of e-commerce on natural environment with positively and negatively sides and assesses the environmental and cost effects of different delivery systems. Mangiaracina et al. (2015) presented environmental and other effects of e-commerce in various part of supply chain. There have been various potential opportunities of e-commerce to reduce greenhouse gas emission in the food production and consumption system. E-Grocery home delivery system was chosen as the fundamental argument of a case study because Electronic Grocery Shopping includes both of direct and indirect impacts to reduce GHG emission in the food sector.

Up to now, many researchers studied environmental impact of e-commerce with different perspectives. But, none of them studied environmental effect of e-logistics activities. In this study, we list the criteria of all environmental effects of e-logistics activity. In addition, we use AHP method to rank and assign each criteria.

\section{Methodology: AHP}

The aim of this study is to determine the effects of e-logistic activities on the environment and to find their weight. AHP method will be used to find the weight of each effect. AHP was developed by Saaty in (1977: 235, 1980:7) and used in the solution of multi-criteria problems. AHP allows each criteria evaluation and optimization of the results. The AHP is a multi criteria decision making method that allows the simultaneous consideration of not only financial but also non-financial, yet quantifiable and qualitative, intangible criteria (Oeltjenbruns et al. 1995:191).

The five-stage AHP set out by Saaty (1980:8) is summarized as follows:

Step 1. Identify the problem \& determine the objective

Step 2. Development of the hierarchy from the top through the intermediate levels to the lowest level 


\section{C. Çakılcı - Y. Öztürkoğlu 12/1 (2020) 489-497}

Step 3. Make a simple pair-wise comparison matrix for each of the lower levels

Step 4. Undertake a consistency test: The $\lambda_{\max }$ value is an important validating parameter in AHP. It is used as a reference index to screen information by calculating the consistency ratio CR (Saaty, 2000) of the estimated vector in order to validate whether the pair-wise comparison matrix provides a completely consistent evaluation. The consistency ratio is calculated as per the following steps:

Step 4.1 Compute the eigenvector or the relative weights and $\lambda$ max for each matrix of order $n$

Step 4.2 Calculate the consistency index for each matrix of order $\mathrm{n}$ by the formula:

$$
\mathrm{CI}=\left(\lambda_{\max }-n\right) /(n-1)
$$

Step 4.3 Calculate the consistency ratio:

$$
\mathrm{CR}=\text { Consistency Index / Random Consistency Index }
$$

The acceptable CR range varies based on the size of matrix, if $n>=5$ than 0.1 is acceptable (Saaty, 2000, Cheng and Li, 2001: 63).

Step 5. Calculate relative weights of the components of each level

\section{Implication}

Sustainable e-logistics activities, which are the main subject of this study; It means managing to support the tripartite profitability (TBL) approach, where social, economic and environmental dimensions are addressed simultaneously. Elkington (1997) introduced TBL model, where environmental dimension is integrated with economic and social dimensions of sustainability.

After a detailed literature review, we determined the main and the sub criteria of the environmental effects of e-logistics based on triple bottom line perspective. There are three main criteria determined which is directly related with e-logistics operations. These are transportation, energy and packaging consumption. Each three main criteria has two sub criteria which is classify as social, economic and environmental classes.

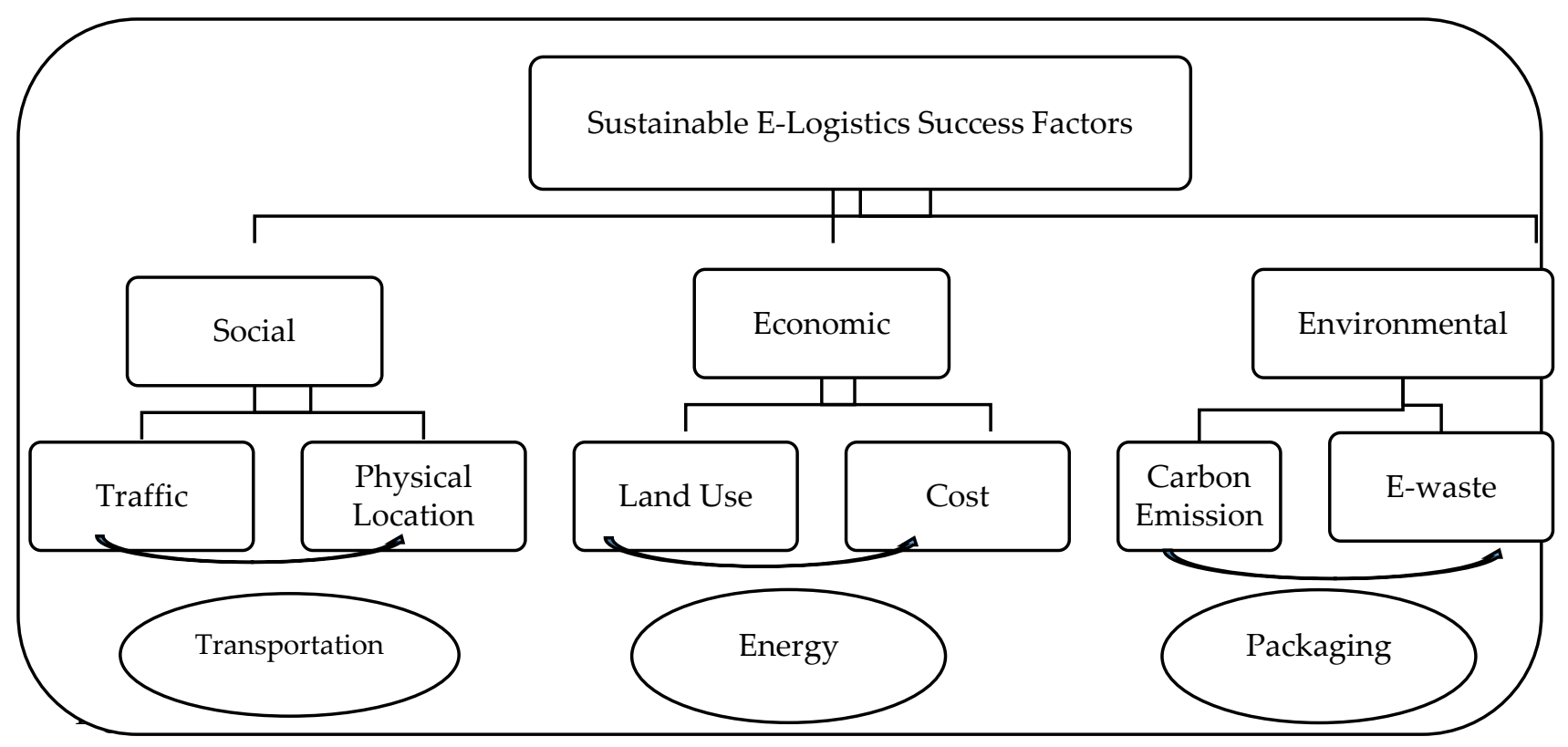

As mentioned above, e-logistics activities are economically important, especially for developing countries, so it is critical that companies in this industry develop an appropriate managerial perspective. To achieve sustainability in terms of the business dimension, e-logistics companies must develop themselves in relation to the following six criteria:

Transportation: E-logistics is interested in both personal travel and freight transportation (FT). Home delivery generates more freight trips and more vehicle kilometers travelled, which affect congestion in traffic, energy consumption, air pollution as well as noise pollution dramatically. In the event that orders are not delivered 


\section{C. Çakılcı - Y. Öztürkoğlu 12/1 (2020) 489-497}

to customers, deliverer needs additional journey from delivery address to distribution center, from the distribution center to delivery address again. On the other hand, customers can visit to cargo center to get their packing or sales return by their own car, which causes to increase fuel consumption as to personal distance travelled and types of vehicles.

Traffic: In E-logistics, where the huge amount of individual orders per a day are delivered to customer's home or office by land transportation, congestion in traffic in parallel with increased the numbers of vehicle on the road affects accident risk, noise pollution and response speed for orders.

Physical location: In order to increase flexibility and convenience for customer's orders, warehouses should be located anywhere with good access to transport facilities. Otherwise, energy use would be increased associated with travelling distance and delivery time would be enlarged.

Energy: Energy refers electricity consumption occurred by machines and buildings. Warehouses need the higher capacity storage area with high ceilings to further increase their volume. Thus, larger and more energy usage is going to be needed.

Land use: Land use can be defined the management and modification of natural environment or build environment. E-commerce significantly affects land use policy. In particular, with the growing of e-commerce, more warehouses as well as fewer stores have become to be needed for retailer businesses. It is possible to say, warehouses are going to shape the future geography and economy of cities and regions.

Emission: Packaging plays a vital role in protecting and preserving orders from distribution until end-user in a safe condition. In E-logistics, more packaging and labelling for orders are used. So, the large amount of materials to produce the packaging would be needed, which cause a significant impact to increase the carbon emission and greenhouse gas emissions and it directly contributes to potential global warming.

A survey was designed for data collection, and the format was synthesized with reference to AHP matrix proposed by Saaty (1980). Ten experts are replied and expressed their interest in conducting the AHP survey. Experts were selected based on their experiences in the e-commerce and e-logistics sector, who have at least ten years of experience in the field. AHP was used separately to determine importance of the each sub-criteria based on TBL dimension.

After collecting the data from the experts, a pairwise comparison matrix was prepared and the weights of the each sub-criteria was calculated (Table 1).

Table 1: Pairwise Comparison Matrix

\begin{tabular}{|l|c|c|c|c|c|c|c|}
\hline Sub-criteria & Traffic & Phys. Loc. & Land Use & Cost & Carb. Emis. & E-waste & Weights \\
\hline Traffic & 1 & $1 / 5$ & 3 & $1 / 3$ & $1 / 7$ & 3 & 0,075 \\
\hline Phy. Loc. & 5 & 1 & 7 & 3 & 1 & 7 & 0,323 \\
\hline Land Use & $1 / 3$ & $1 / 7$ & 1 & $1 / 7$ & $1 / 7$ & $1 / 3$ & 0,032 \\
\hline Cost & 3 & $1 / 3$ & 7 & 1 & $1 / 3$ & 7 & 0,179 \\
\hline Carb. Emis. & 7 & 1 & 7 & 3 & 1 & 7 & 0,343 \\
\hline E-waste & $1 / 3$ & $1 / 7$ & 3 & $1 / 7$ & $1 / 7$ & 1 & 0,048 \\
\hline \multicolumn{7}{|r|}{} \\
\hline
\end{tabular}

Table 2: Normalize Comparison Matrix

\begin{tabular}{|l|c|c|c|c|c|c|}
\hline Sub-criteria & Traffic & Phys. Loc. & Land Use & Cost & Carb. Emis. & E-waste \\
\hline Traffic & 0,060 & 0,072 & 0,107 & 0,043 & 0,052 & 0,119 \\
\hline Phy. Loc. & 0,300 & 0,355 & 0,250 & 0,394 & 0,362 & 0,276 \\
\hline Land Use & 0,020 & 0,050 & 0,036 & 0,019 & 0,052 & 0,013 \\
\hline Cost & 0,180 & 0,118 & 0,250 & 0,131 & 0,120 & 0,276 \\
\hline Carb. Emis. & 0,420 & 0,355 & 0,250 & 0,394 & 0,362 & 0,276 \\
\hline E-waste & 0,020 & 0,050 & 0,107 & 0,019 & 0,052 & 0,040 \\
\hline Total & 1 & 1 & 1 & 1 & 1 & 1 \\
\hline
\end{tabular}

The last stage of the AHP analysis is to calculate the importance level of each criteria. The most important subcriteria is the carbon emission. Physical location, cost and traffic are the other important criteria based on the 


\section{C. Çakılcı - Y. Öztürkoğlu 12/1 (2020) 489-497}

e-logistics activities in terms of sustainability perspective. In order to control the results, the consistency ratio should be calculated. Consistency ratio of 0,10 or less is acceptable to trust the AHP analysis. In our consistency ratio is 0,067 , which is acceptable.

Table 3: Overall Results

\begin{tabular}{|l|c|c|c|c|c|c|}
\hline & \multicolumn{6}{c|}{ Triple Bottom Line } \\
\hline Dimensions & \multicolumn{2}{|c|}{ Social } & \multicolumn{2}{c|}{ Economic } & \multicolumn{2}{c|}{ Environment } \\
\hline Factors & Traffic & Phys. Loc. & Land Use & Cost & Carb. Emis. & E-waste \\
\hline Weights & 0,075 & 0,323 & 0,032 & 0,179 & 0,343 & 0,048 \\
\hline Ranks & 4 & 2 & 6 & 3 & 1 & 5 \\
\hline \multicolumn{7}{|c|}{ Consistency Rate: 0,067} \\
\hline
\end{tabular}

The AHP results showed that emission has a priority weight of e-logistics, while land use has the lowest weight among all these e-logistics factors. It is very interesting that e-waste is ranked almost at the end of the list.

According to these results, the internet shopping and emission is directly linked in terms of environmental. A rise in internet shopping causes to increase significantly carbon emission. The social dimension of sustainability affects the use of physical places. Consumers are now shopping online rather than shopping at physical stores. Therefore, the stores are closing and socially different consequences arise. When the results are taken from the economic point of view, logistics costs are highly affected. Companies need to close stores and open a warehouse or distribution center. The location of the internet users and their proximity to the market is not distributed homogeneously because of the choice of storage location has become very important. Again, customers' orders of different time and quantities affect the packaging and transportation costs.

\section{Conclusion}

Along with the changes in consumer behavior, shopping patterns have begun to change as well. Especially with the spread of the internet, traditional shopping style has decreased considerably. There are many positive aspects for consumers to shop online. However, it has negative effects on the environment, employment and many other aspects. With the increase in online shopping, e-logistics is one of the newest concepts introducing the literature. In the literature, there are many studies about online shopping and e-logistics.

In general, there are lots of study, which is related about e-logistics activities. However, there is a lack in knowledge in terms of integrating sustainability and TBL with e-logistics activities. Therefore, this is the first study to fill that gap in the literature. Therefore, in this study, e-logistics activities are examined under the triple bottom line perspective of the sustainability with all three dimensions. Firstly, a detailed literature review conducted to determine the all impacts of e-logistics activities. Three main and six sub-criteria were determined and these criteria were divided into classes according to the triple bottom line perspective. These variables are investigated by using $\mathrm{AHP}$, one of the decision-making techniques, to rank and assign weight of each sub-criterion. The AHP results showed that carbon emission has a priority weight of e-logistics. After emission, physical location is the second place. Land use has the lower weight that means, there is a little effect of e-logistics activities and e-waste is almost at the end of the list.

As a result, this study made inferences by addressing three dimensions of sustainability simultaneously and integrating them into e-logistics operations. The results can provide mutual gains both for manufacturers and retailers and for customers.

\section{References}

Abukhader, S., \& Jonson, G. (2003). Environmental implications of E-commerce - A Critical Review and framework for future investigation. Management of Environmental Quality: An International Journal, 14(4), 460-476.

Arnfalk, P. (1999). Information technology in pollution prevention: Teleconferencing and telework used as tools in the reduction of work related travel. IIIEE Dissertation, (1999:1), International Institute for Industrial Environmental Economics (IIIEE), Lund University, Lund, Sweden.

Auramo, J., Aminoff, A., \& Punakivi, M. (2002). Research agenda for e-business logistics based on professional opinions. International Journal of Physical Distribution \& Logistics Management, 32(7), 513-531. 


\section{C. Çakılcı - Y. Öztürkoğlu 12/1 (2020) 489-497}

Berkhout, F., \& Hertin, J. (2004). De-materialising and Re-materialising: Digital Technologies and the Environment. Futures, 36(8), 903-920.

Bertram, R.F., \& Chi, T. (2018). A study of companies' business responses to fashion e-commerce's environmental impact. International Journal of Fashion Design, Technology and Education, 11(2), 254-264.

Calıskan, A., Kalkan, M., \& Ozturkoglu, Y. (2017). City logistics: problems and recovery proposals. International Journal of Logistics Systems and Management, 26(2), 145-162.

Cairns , S. (1999). The home delivery of shopping: the environmental consequences, TSU Working Paper, ESRC Transport Studies Unit, University of London, London, England.

Caudill, R., Luo, Y., Wirojanagud, P., \& Zhou, M. (2001). A life cycle environmental study of the impact of ecommerce on electronic products. Proceedings of the 2000 Institute of Electric and Electronics Engineering (IIIEE) International Symposium on Electronics and the Environment, USA.

Cheng, E. W., \& Li, H. (2001). Information priority-setting for better resource allocation using analytic hierarchy process (AHP). Information Management \& Computer Security, 9(2), 61-70.

Dalgakıran, A. B., \& Öztürkoğlu, Y. (2017). Scale and relationship analysis for Turkish furniture sector. Business $\mathcal{E}$ Management Studies: An International Journal, 5(1), 147.

Daniel, E. M., \& Grimshaw, D. J. (2002). An exploratory comparison of electronic commerce adoption in large and small enterprises. Journal of Information Technology, 17(3), 133-147.

Dumlupınar, M. T., \& Öztürkoğlu, Y. (2019). Tehlikeli madde taşimaciliğinda adr'ye göre risklerin analiz edilmesi. Trakya Üniversitesi Sosyal Bilimler Dergisi, 21(1), 1-13.

Edwards, J. B., Mckinnon, A., \& Cullinane, S. (2010). Comparative analysis of the carbon footprints of conventional and online retailing: A 'last mile' perspective. International Journal of Physical Distribution $\mathcal{E}$ Logistics Management, 40(1/2), 103-123,

Fichter, K. (2008). E-commerce: Sorting out the environmental consequences. Journal of Industrial Ecology, 6 (2), 25-41.

Hesse, M. (2002). Shipping news: the implications of electronic commerce for logistics and freight transport. Resources, Conservation and Recycling, 36, 211-240.

Hurst, E. (2001). E-Commerce and the Environment, MSc thesis, Imperial College of Science, Technology and Medicine, University of London, England.

Khurana, H., Goel, M.K., Singh, H., \& Bhutani, L. (2011). E-commerce: role of e-commerce in today's business. International Journal of Business Management Research, 1(7), 454-461.

Macauley, M., Palmer, K., \& Shih, J. S. (2003). Dealing with electronic waste: modelling the costs and environmental benefits of computer monitor disposal. Journal of Environmental Management, 68(1), 1322.

Mangiaracina, R., Marchet, G., Perotti, S., \& Tumino, A. (2015). A review of the environmental implications of B2C e-commerce: a logistics perspective. International Journal of Physical Distribution \& Logistics Management, 45(6), 565-591.

Manzoor, A. (2010). E-commerce: An introduction. Lambert Academic Publishing.

Matthews, H.S., Williams, E., Tagami, T., \& Hendrickson, C. T. (2002). Energy implications of online book retailing in the United States and Japan. Environmental Impact Assessment Review, 22,493 - 507.

Matthews, H. S., \& Hendrickson, C. T. (2001). Economic and Environmental Implications of Online Retailing in the United States. EnviroInfo 2001: Sustainability in the Information Society, 15 th International Symposium on Informatics for Environmental Protection, Metropolis Verlag, Marburg.

Ozturkoglu, Y., Ozbiltekin, M., Gozacan, N., \& Surgec, I. (2016). City Logistics: Sample Implementation of Izmir City. Journal of Management Marketing and Logistics, 5(3), 206-213.

OECD (Organisation for Economic Cooperation and Development). 2001. OECD science, technology, and industry scoreboard: Towards a knowledge-based economy. Paris: OECD.

Oeltjenbruns, H., Kolarik, W. J., \& Schnadt-Kirschner, R. (1995). Strategic planning in manufacturing systems - AHP application to an equipment replacement decision. International Journal of Production Economics, 38(2-3), 189-197. 


\section{C. Çakılcı - Y. Öztürkoğlu 12/1 (2020) 489-497}

Oláh,J., Kitukutha,N., Haddad,H., Pakurár,M.,Máté,D., \& Popp,J. (2018).Achieving sustainable e-commerce in environmental, social and economic dimensions by taking possible trade-offs. Sustainability, 11(1), 89.

Orremo, F., \& Wallin, C. (2000). IT, Food and Environment, an environmental analysis of electronic trade of groceries. Report No. 5038, The Swedish Environmental Protection Agency, Stockholm.

Öztürkoğlu, Y., \& Demir, B. (2019). E-ticarette tüketicilerin güvenlik ve risk algılarının değerlendirilmesi. MANAS Sosyal Araştırmalar Dergisi, 8(2), 1906-1915.

Pålsson,H., Hiselius, L., \& Pettersson, F. (2017). Energy consumption in e-commerce versus conventional trade channels Insights into packaging, the last mile, unsold products and product returns. Journal of Cleaner Production, 164, 765-778.

Padayachee, K. (2008). Utilizing E-Commerce and M-Commerce Applications to Address the Effect of Global Warming. E-leader, Krakow 2008.

Prouty, K. (2000). Flow manufacturing: An answer to e-business. Material Handling Management 55(5), 67-70.

Reijnders, L., \& Hoogeveen, M. J. (2001). Energy effects associated with e-commerce: A case-study concerning online sales of personal computers in The Netherlands. Journal of Environmental Management, 62(3), 317321.

Romm, J., Rosenfeld, A., \& Herrmann, S. (1999). The Internet Economy and Global Warming: A Scenario of the Impact of E-commerce on Energy and the Environment. The Center for Energy and Climate Solutions, the Global Environment and Technology Foundation.

Saaty, T. L. (1977). A scaling method for priorities in hierarchical structures. Journal of Mathematical Psychology, 15(3), 234-281.

Saaty, T. L. (1980). The analytic hierarchy process McGraw-Hill. New York, 324.

Saaty, T. L. (2000). Fundamentals of decision-making and priority theory with the analytic hierarchy process. RWS Publications, 6.

Sabegh, M. H. Z., Ozturkoglu, Y., \& Kim, T. (2016). Green supply chain management practices' effect on the performance of Turkish business relationships. International Journal of Supply and Operations Management, 2(4), 982-1002.

Siikavirta, H., Punakivi, M., Kärkkäinen, M., \& Linnanen, L. (2002). Effects of e-commerce on greenhouse gas emissions: a case study of grocery home delivery in Finland. Journal of Industrial Ecology, 6(2), 83-97.

Sui, D. Z., \& Rejeski, D. W. (2002). Environmental impacts of the emerging digital economy: the e-forenvironment e-commerce? Environmental Management, 29(2), 155-163

Tiwari, S., \& Singh, P. (2011). Environmental Impacts of E-commerce. 2011 International Conference on Environment Science and Engineering, 8, 202-207.

Tuerk, V. (2001). Assessing the resource intensity of the Internet structure. Master's Thesis, International Institute of Industrial Environmental Economics, Lund University, Lund, Sweden.

Toffel , M. W., \& Horvath, A. (2004). Environmental implications of wireless technologies: news delivery and business meetings. Environmental Science and Technology, 38(11), 2961-2970.

Yi, L., \& Thomas, H. R. (2007). A review of research on the environmental impact of e-business and ICT. Environment International, 33(6), 841-849.

Williams, E., \& Tagami, T. (2001). Energy analysis of e-commerce and conventional retail distribution of books in Japan. In Sustainability in the Information Society, 15th International Symposium on Informatics for Environmental Protection. Metropolis Verlag. 